\title{
Insurgent Rule as Sovereign Mimicry and Mutation: Governance, Kingship, and Violence in Civil Wars
}

\author{
BART KLEM \\ Development Studies, University of Melbourne
}

SIDHARTHAN MAUNAGURU

South Asian Studies Programme, National University of Singapore

\section{IN TR O DUCTION}

Contested environments, like civil wars, are of particular interest to our understanding of sovereignty, because there are multiple claimants to sovereign rule. In this article we explore one such sovereign aspirant: the Liberation Tigers of Tamil Eelam. The LTTE emerged as the primary ethno-separatist militia in Sri Lanka's civil war in the 1980s and succeeded in developing a repertoire of sovereignty in the northeast of the island until their comprehensive defeat in 2009. Our analysis of LTTE rule highlights a central paradox: the movement displayed itself as a systematic entity with the procedures and trappings of modern governance, but at the same time it preserved its mythical cult status as an untamable and intractable entity. The former was all about being orderly, territorial, bounded, bureaucratic, procedural, and stable; the latter evolved around the opposite qualities of being elusive, unsettled, unbounded, transcendental, unpredictable, and capricious.

Acknowledgments: The authors thank the CSSH reviewers and editorial team for a very thorough, constructive, and generous review process. For useful discussions and detailed comments on earlier drafts, we thank Roland Bleiker, Georg Frerks, Amanda Gilbertson, Jonathan Goodhand, Benedikt Korf, and Jonathan Spencer. We are also grateful to all those who have contributed to our research over the years as translators, assistants, and participants. Bart Klem would like to acknowledge the research funding provided by the Swiss National Science Foundation (grant numbers 100017_149183/1 and PDFMP1-123181/1). Sidharthan Maunaguru acknowledges research funding provided by the Newton Fellowship funded by British Academy and the Royal Society. 
It is no coincidence, in our view, that the LTTE deployed such paradoxical registers in its sovereign pursuit. After all, some of the seminal works on political theology and divine kingship have underscored the fundamental and arguably irresolvable tensions at the heart of sovereignty (Geertz 1980; Gilmartin 2015; Hansen 2001; Heesterman 1985; Kantorowicz 1997 [1957]; Schmitt 2005 [1922]; Spencer 2007). Sovereignty straddles different idioms of power, and it is steeped both in the mundane roots of society and a sublime beyond. Rather than trying to resolve the above puzzle around LTTE rule, then, it may be more interesting to keep the paradox between orderly governance and capricious rule in check. The co-occurrence of these paradoxical qualities is no sign of sovereign failure or incompletion, and indeed it is inherent to what sovereignty is.

We argue that an insurgency like the LTTE must be understood, not simply as an (unsuccessful) attempt at rebel governance, but rather as a precarious articulation of sovereignty. We combine three conceptual strands: Hansen and Stepputat's work on "de facto sovereignty" (2005; 2006), Cynthia Weber's on sovereignty as simulated practice (1995; 1998), and Homi Bhabha's on mimicry (1994). In doing so, we suggest that insurgent movements are not merely vying to be assimilated into the community of sovereign states. They are also capable of subtly rearticulating the way sovereignty is understood and practiced. Rebel movements with state-like ambitions are not simply lagging behind purportedly normal states, struggling toward some fixed yardstick of sovereignty. They are better thought of as laboratories of sovereign rule that actively transform the way sovereignty is practiced and understood.

Understanding insurgencies like the LTTE as laboratories of rule in the global margins opens up productive space for incisive comparative perspectives. Historically, interesting parallels emerge between LTTE rule and iterations of sovereign rule during some of the more unsettling junctures of South Asia's colonial and postcolonial past (e.g., Gilmartin 2015; Heesterman 1985; Mongia 2007; Mukherjee 2010; Purushotham 2015). Thematically, we posit there is scope for a comparative political theology of rebel rulers, elaborating on the existing, but somewhat disparate, work along these lines (Degregori 2012; Staniland 2014; Wood 2008). Exploring the mystical and transcendental repertoires of insurgent rule as central planks of the sovereign project rather than as mere tactical accessories can enrich the emergent literature on rebel governance in political science. This work is exciting but has largely steered clear of the issues raised in this article (e.g., Arjona, Kasfir, and Mampilly 2015; Caspersen 2012). A thorough discussion of these historical and thematic lines of inquiry is both beyond this article's scope and our empirical expertise, but we will make some provisional observations in the paper's final sections, which we believe warrant further scholarly engagement. 
This article emerged from a drawn-out discussion between its authors and builds on a diverse set of data and experiences rather than a single methodological effort. Sidharthan grew up in northeastern Sri Lanka during the Tamil insurgency, was part of the society that the LTTE sought to rule, and witnessed some of the movement's sovereign efforts as they unfolded. He subsequently left Sri Lanka and commenced a scholarly career. Bart gained his first experience with the LTTE during fieldwork in Sri Lanka's northeast in 2000. His later research efforts involved academic inquiry and also consultancy assignments associated with the 2002 ceasefire agreement and the peace talks that followed. Our methodological basis thus includes classical ethnographic methods (observations, interviews), reflections on policy research, and personal life experiences. Simply put, we might say that Sidharthan found himself on the inside of the LTTE's sovereign project and worked his way out while Bart started on the outside and tried to work his way in.

CONCEPTUALIZING SOVEREIGNTY: MIMICRY, VIOLENCE, AND DIVINE KINGSHIP

Sovereignty has not lost its purchase as a commonsensical term pivoting on the convergence of people, state, and territory, and associated notions of selfdetermination, supreme authority, and an international order based on noninterference between nation-states. Conceived as such, however, it has rather limited heuristic value. As Rob Walker put it over two decades ago, "Despite all appearances, sovereignty is not a permanent principle of political order; the appearance of permanence is simply an effect of complex practices working to affirm continuities and to shift disruptions and dangers to the margin" (1993: 163).

There is no dearth of scholarly efforts to interrogate sovereignty as a selfevident prerogative of nation-states. In fact, the literature on the subject is so rich and diverse that the term seems to have only become more elusive. Rather than embarking on a comprehensive discussion or settling for a narrow definition, we will use this section to make three broad points to clarify how we conceptualize sovereignty. The first elaborates the abovementioned idea that sovereignty is enacted through mimicry and mutation, the second brings sovereignty's central tenet - violence - to the fore, and the third elaborates on the paradox between the orderly and the capricious aspects of sovereignty.

Firstly, we conceive of sovereignty as a set of ideas and practices that evolves through citational cycles. This can help us grapple with the fact that sovereignty is historically contingent: it has meant different things to different people in different times and places (Bartelson 1995; Walker 1993; Weber 1998). This is no less true in Europe than in South Asia. The historical scholarship on the latter region shows that sovereign ideas and practices did not simply result from colonial impositions, with ideas radiating out from the European 
center to colonial peripheries (Beverley 2013; Gilmartin 2015; Moin 2015; Mongia 2007; Mukherjee 2010; Purushotham 2015). Rather, they emerged from the colonial encounter itself, affecting both the colonizers and the colonized (Mongia 2007). Competing discourses of sovereignty evolved in contingent ways, and in the process they redefined political community, legality, and the legitimate basis of rule (Mukherjee 2010). This historical articulation of sovereignty did not only take place in courtrooms and executive offices, but was also shaped by a long sequence of violent ruptures in society. Political authority was legitimized as a response to raiders and savage threats to the civilized order, both from the extremities of the frontier and from interstitial frontiers like the Muslim Nizam of Hyderabad in the center of colonial India (Beverley 2013). The eventual erasure of these patchworks of territorialized rule involved the arming of some citizens and the killing of others, a chain of violence and sacrifice that endorsed one group's nation concept (India) while reducing other groups (e.g., Hyderabad's Muslims) to religious minorities (Purushotham 2015).

Rather than searching for the foundation of sovereignty - that is, undertaking a futile quest for an objective referent on the basis of which the validity and legitimacy of sovereign rule could be assessed-we instead embrace Cynthia Weber's understanding of sovereignty as a simulated practice. It emerges out of the interplay between the practices of authorizing political order and interpretations thereof. In short, sovereignty is always like something, it never just is (Weber 1998: 95). ${ }^{1}$ Our approach is to combine Weber's idea of citational practice with Homi Bhabha's work on mimicry (1994: 85-92). Bhabha studies the way institutional forms and practices of order and authority were implicated by the globalized encounter of colonialism, both among the colonizers and the colonized, affecting the very nature of sovereign rule. He argues that mimicry is a way of dealing with difference. It is a form of camouflage, but at the same time it always holds the potential to evolve into parody and mockery. Our use of the term mimicry focuses on rulers: how they perform rule by acting like other rulers. Bhabha's central point remains relevant, though: mimicry invariably involves small innovations, slippage, and mutations. It does not result in identical copies, but rather in duplicates that are very similar, but not quite the same (ibid.: 85-92). Furthermore, that which is being duplicated stems from a form of imitation itself; there is no fundamental difference between original and duplicate. There is no a priori reason that mimicked performance should be less authentic than that which it seeks to imitate. Or, to link back to Weber's idea of sovereignty as citational practice, there is no

\footnotetext{
${ }^{1}$ For a similar analysis of theatrical efforts to simulate what is considered to be credible and desirable state conduct, see Lisa Wedeen's work on newly unified Yemen "seeing like a citizen, acting like a state" (2003).
} 
etymological root to the citation, no sovereign "gold standard" from which state conduct can be derived.

While it is helpful to think of sovereignty in these terms, it must also be clear that sovereignty is not just any kind of political performance. It may have mutated over the centuries, but some qualities are essential to it. That brings us to our second basic conceptual point: sovereign rule involves a form of order that is backed up by disciplinary violence and does not yield to superior force. We are building here on the work of Hansen and Stepputat $(2005 ; 2006)$, who coined the heuristically useful catchphrase of "de facto sovereignty" as the "ability to kill, punish and discipline with impunity" (2006: 295). Defined this way, sovereignty is obviously no longer a state prerogative. Political strongmen, kangaroo courts, and rebel movements may be called de facto sovereign in this view when they invent their own rules, enforce them with coercive means, and are able to sustain this practice, without themselves being reined in by a more powerful disciplinary order.

The idea that sovereignty involves the ability to make and break the law is a familiar one, of course. There has been a significant amount of renewed scholarly attention for Schmitt's conception of sovereignty as the ability to declare an exception - central is the ability, not to enforce law, but to suspend it - and for Agamben's reinterpretation of the state of exception (2005) as the legal root of modern state brutality and disregard for human life, be it in Auschwitz or Guantánamo Bay. There is an implicit element of exception in the notion of de facto sovereignty - the ability to withstand existing rules and supplant them with new ones - but we will not engage with that literature in any detail. Reorienting debates on the fledgling democracy of the Weimar Republic, the inadvertent delivery room of the apparatus that would bring Europe unprecedented violent excess, toward the convoluted political landscapes of contemporary insurgency, conjures up a range of inadequacies. Yes, we see aspiring sovereigns making and breaking law, but the forms of order they impose are typically precarious. They are violent, to be sure, but they are not the totalizing, industrious "killing machine" that features in the state of exception (ibid.: 86). The political landscapes in which they take place are more diverse and morphed by competing claimants to rule. Finally, legal finesse seems to play a rather secondary role in legitimizing exceptional violence among insurgent rulers.

Let us thus return to Hansen and Stepputat's work, which, beyond coining the phrase de facto sovereignty, provides a useful entry into the literature on divine kingship. Our third point, which is situated within this literature, concerns the sovereign paradox. We will approach this via the scholarship in political anthropology, which conceives of sovereignty as a form of divine kingship. Hansen and Stepputat conceive of sovereignty as "a tentative and always emergent form of authority grounded in violence that is performed and designed to generate loyalty, fear, and legitimacy" (2006: 297). Rule enforcement, backed by violence, is certainly essential, but there is something more, and more 
fundamental and awe-inspiring, about sovereignty. Sovereignty has religious as well as political qualities, and this "fetishization of sovereign power," Hansen and Stepputat observe, "is by no means limited to societies beyond the West" (ibid.: 305). It in fact resonates with observations across the globe and throughout history (Burghart 1996; Geertz 1980; Hansen 2001; Hocart 1941 [1927]; Spencer 2007). In many societies kingship is thought to have a cosmic base that ties a community together, endowing people with genealogy and existential meaning. Modern political rule has evolved away from some of these ideas, but still carries their mark and can thus be thought of as a form of secularized theology (Schmitt's famous argument [2005 (1922): 36-52]). Examples include the worship of kingly portraits in Thailand (Stengs 2008), the lordship of political entrepreneurs in Nepal (Burghart 1996), the political potency of deities in India (Singh 2012), the posthumous idolatry of Lady Di (Watson 1997), and the political ritual around presidential performance in France (Abeles 1988).

These ideas about divine kingship and political theology put us in a good position to come to grips with the paradox alluded to in our introduction. Thinking of sovereignty as a form of rule that combines religious and political qualities fixes our gaze on the central conundrum, which, as aptly summed up by David Gilmartin, comes down to the following. ${ }^{2}$ Sovereigns need "to be effective agents of order (and governance) in the mundane political world (and thus to be effectively engaged with all the community's conflicts and divisions)." Yet at the same time they need to "transcend all society's conflicts and divisions, standing apart from them and embodying the community (and the polity) as a unity" (Gilmartin 2015: 373). Sovereignty thus has to be both part of society and external to it, both interested and disinterested.

This disjuncture at the heart of sovereign rule has been a familiar feature throughout the European history of kingship. The king, after all, unites a fallible, mortal persona with an impeccable, eternal institution, a profane "body natural" and a sublime "body politic" (or corpus mysticum), which embodies the law and, not uncommonly, God's will (Kantorowicz 1997 [1957]). Interestingly, we find a strikingly similar sovereign paradox in the genealogy of royal authority in India. Heesterman (1985) discusses the way ancient Sanskrit texts describe how kings must be part of their community's moral order (dharma), but derive their authority from a realm beyond that community, from an alien, uncivilized, ungraspable outside, often represented as the jungle (aranya). Divine kingship thus straddles the boundaries of a community's inside and outside.

\footnotetext{
${ }^{2}$ Hansen and Stepputat conceive of the sovereign paradox in similar terms when they posit that this tension stands "at the heart of modern sovereignty"; that is, the tension between "the sovereign in its ideal and transcendent form (nation, state, the people)" and "their always transient and imperfect embodiment in a specific leader, party, movement, or constitution" (2006: 301).
} 
Not unlike deities, sovereigns have both a benign side and a violent side. Heesterman discusses the sovereign capacity to unleash excessive violence, particularly in precarious circumstances. Spectacular violence is performed to "set the record straight." The point is not that there are benign kings who protect their people, and evil kings who torment or even devour them-all kings embody both capacities (ibid.; see also Gilmartin 2012; 2015; Hansen 2001). This does not disqualify the basic idea of sovereignty as discipline with impunity, but it does mean that we have to expand our gaze beyond a purely instrumental deployment of violence. Evidently, disciplinary violence is essential to the operation of sovereign rule, but sovereignty understood in terms of divine kingship is more capricious than that. It harbors the potency of excessive violence, a disregard for human life. It does not only deploy violence as a measured compliance instrument, but also to display an untamable force that instills awe.

In sum, we conceive of sovereignty as a form of rule that hinges on authorizing practices backed up by disciplinary and spectacular violence. Such rule is articulated through mimicry, which borrows from different registers - religious and political, from within or beyond society. At the heart of sovereign rule we find a persistent, irresolvable paradox between the profane element of orderly governance and the sublime element of mystical (and potentially capricious) conduct. We will discuss the case of the LTTE, to which we now turn, in this same order. The next section focuses on the way its governance structures evolved. This is followed by a brief link back to the rebel governance literature, after which we proceed to the more mystical and capricious elements of the LTTE's sovereign project.

\section{LTTE RULE AS ORDERLY AUTONOMOUS GOVERNANCE}

Sri Lanka's ethno-political conflict, riots, pogroms, and civil war are well documented. In a nutshell, the island's history has been described as a story of the competing ethno-nationalisms of the Sinhala majority and the Tamil minority (later followed by Muslim efforts to articulate an ethno-political agenda), and a postcolonial democratic state that aggravated rather than quelled these sentiments (Hoole 2001; Stokke and Uyangoda 2011; Wickramasinghe 2006; Winslow and Woost 2004). Political pleas for autonomy in the Tamildominated northeast brought no meaningful results. This was the historical context from which the space for a militant sovereign experiment emerged.

Sidharthan was standing by the garden gate on a Sunday morning in the mid-1980s when LTTE fighters came walking through the streets of Jaffna, the main town in the Tamil-dominated north of Sri Lanka. Their shirts and trousers were wet and their feet were bare. The street was lined with people who had come out of their houses to look, some of whom handed water and food to the combatants as they passed. There was excitement, since until then the militants had been talked about, but they would not display themselves so 
publicly. Rumors about them had frantically circulated and news reports had mentioned attacks on the army and assassinations of prominent figures. People whispered about friends and relatives who had disappeared and were thought to have joined the movement. Occasionally, one would see militants cycling around and posters on walls called for people to join them. Corpses were found sometimes, and when people heard dogs barking at night they thought about fighters roaming around. But this day the movement came out in the open, walking on the street where everyone could see them. The onlookers knew that they had attacked the Sri Lankan army at their barracks and returned victoriously. In doing so, they had created something that had hitherto seemed illusionary: a Tamil space, a territory beyond the army's grasp where the rebels roamed freely.

People had come to call the militants "our boys" (namada podiyankal), a term that signified a form of kinship, a familial bond. After that day, people talked more openly and sometimes proudly about relatives who had joined the movement. In the early years of the militancy there was a proliferation of Tamil militant movements: new ones emerged and old ones split (HellmannRajanayagam 1994a: 40-53; 1994b; Thiranagama 2010). But at that time people did not distinguished so clearly between them. Many had an overriding feeling that all militants were fighting for the rights of a Tamil nation and a separate state. People offered them food parcels, money, and shelter because the militants were seen to be seeking redress for the suffering that the Sri Lankan government had inflicted on the Tamils. There was awe and admiration in the stories that circulated about them - about how a few boys had attacked a major army camp, miraculous escapes from the army, the militants' remarkable ability to plan and organize things, and the foresight of their leaders. An increasing number of these "boys" were in fact girls. Transgressing prevalent cultural boundaries, these women - their willingness to fight, their ability to assume authority, their outfit of pants, belts, and braids - became a subject of fascination. They represented violent authority, but they were also bounded subjects over whom great power was exercised (Brun 2008; Maunaguru 1995; Schalk 1997a; Thiranagama 2011: 183-227; Trawick 2007).

At first the line between militants and the community was blurry. When people joined the militant movements they would be given a nom de guerre and began living separate lives. They transformed from known into unknown figures, into fighters with unrivalled valor. But at the same time an element of closeness between family members was preserved. Militants were dual figures, humans with supra-human powers. In time, however, their powers were deployed to not only protect but also discipline the community. In 1985, the LTTE proclaimed itself the sole representative of the Tamil cause and branded all those who thought otherwise as traitors. It captured and murdered many fighters from the other militant movements and killed and burned some of them publically. People who openly opposed such killings 
were kidnapped or otherwise silenced (Hoole 2001). These events instilled terror among the Tamil community.

The initial closeness between civilians and militants thus eroded and the LTTE increasingly severed its cadres from society. As Sharika Thiranagama has noted (2011: 183-227), the movement developed a new, horizontal form of kinship: youngsters turned their back on the gerontocratic and gendered traditions of Tamil society and called their comrades "brother" or "sister." The glorifying cult around cadres transmitted in LTTE propaganda made it clear that these fighters were not normal Tamils: they lived exceptional lives and died exceptional deaths. The Eela Murasu, the movement's unofficial newspaper, carried militants' life stories with diary notes, glorifying poems, and stories about military achievements. Cadres drove around in armed convoys.

Heroes and traitors are to some extent two sides of one coin, Thiranagama posits (ibid.). The same intimacy that enables the camaraderie of heroic warriors also grounds the wrath toward traitors. It is intimate knowledge that makes inside enemies dangerous, and it is often through intimate knowledge that they are exposed. The brutal violence of cleansing the Tamil community from such internal evil thus redefined that community as a nation protected by heroes, purified from traitors, and bounded by the shared, secret knowledge of what violence the movement could inflict on every individual Tamil. Demarcating a purified Tamil nation also entailed expelling hybrid categories, most obviously the Muslim community, which had initially been rendered a tacit constituency of Eelam (Islamic Tamils). In 1990, however, the LTTE sought to turn the north into a pure Tamil space by forcefully evicting the Muslims, despite their long history in the region and close cultural ties and affinities with the Tamils (Hasbullah 2001; Thiranagama 2011: 127-31).

The LTTE bolstered its claim to supremacy over the Tamil community by creating different military wings and by mimicking state functions. Movement leaders started adjudicating local disputes. The northern region was divided into sections, within which the respective commanders exercised control. Makeshift institutions were erected to preserve a minimal infrastructure and administer civilian life and the movement began keeping meticulous records. Pamphlets with the LTTE's official seal stipulated rules and proper behavior for the Tamil community. People started to receive LTTE letters inviting them to meetings, and civil servants, university lecturers, and community leaders were absorbed into the LTTE's project of rule.

The LTTE ruled the Jaffna Peninsula from late 1990 into 1995. Visible camps and offices appeared, meting out distinct LTTE spaces and institutions (Schalk 1997a). The creation of an LTTE bank and a new currency and the establishment of a police force and courts gave shape to a so-called "Eelam" state in Jaffna. This process was disrupted when the government drove the insurgents out of Jaffna in 1995. In retreat, the LTTE forced a large part of Jaffna's population to abandon the peninsula and flee with them to the 
Vanni, the scrubby and sparsely inhabited region to the south. The movement controlled most of that region from 1996 until its defeat in 2009, and it was there that its experimentation as an institutional outfit took on its most elaborate form. In the eastern region, where the movement controlled smaller territorial pockets, slightly different and less encompassing forms of rule were elaborated (Klem and Maunaguru n.d.; Korf, Engeler, and Hagmann 2010).

During these years the LTTE transformed its military strategy from one of staging hit and run attacks to coordinating large maneuvers with embattled frontlines, a form of conventional warfare simulating that of the Sri Lankan state $^{3}$ Central to this strategy were the consolidation of territorial control and the imposition of LTTE rule over Tamil soil (mann). The rapid expansion of the LTTE's institutional repertoire after the 2002 ceasefire with the Sri Lankan government was a continuation of this approach. Significant space for LTTE's creative mimicry of the state was opened up by the absence of major military offensives, the government's tacit acknowledgement that the movement ruled particular territories, and new opportunities for public engagement with international actors (see Brun 2008; Klem 2012; Natali 2008; Sarvananthan 2007; Stokke 2006). Like so many foreign diplomats, aid workers, academics, and journalists, one of us, Bart, joined what we can call the "Vanni tour" during this period. This journey typically started at the Omanthai army checkpoint, where travelers left government-controlled space and entered a narrow strip of no man's land on which sat a small station of the International Committee of the Red Cross. Next came an LTTE checkpoint that was constructed like a border compound, complete with flags, signs, barriers, barbwire, and armed officers. One encountered there the newly created Tamil Eelam customs (Tamil Eelam Sungavari Athikari, its officers recognizable by their uniforms with their prominent, tall caps. Persons crossing were subjected to a thorough but efficient procedure that included having their vehicles and passports checked, filling out forms with LTTE letterheads, getting things stamped, and paying an import tax. This was not the sort of barrier that drunken guerrillas and corrupt officers exploit to make a few bucks - this place demarcated the beginning of Tamil Eelam territory as an impeccably-run gateway, endorsed by the presence of international monitors. It was evident from the conduct of the personnel that it was meant to be an improved version of Sri Lankan army checkpoints, which rarely caught any militants but routinely troubled those passing through with inefficient checks and inappropriate questions. We know not what inspired the design of the customs officers' uniform

${ }^{3}$ For a detailed discussion, see Sivaram's reflections as discussed by Mark Whitaker (2007: 139-49). It is likely that the LTTE's military strategy was informed by the failures of Sri Lanka's other insurgency, the Janatha Vimukthi Peramuna (JVP) rebellion of the 1970s and 1980s (Balasingham 2004: 26). For a comparative perspective on the JVP and the LTTE, see Moore (1993). 
(it reminded us of senior French officers in films about the Great War), but it did display a sense of authority and uprightness.

Proceeding on the northbound road through the scrubby and sparsely populated Vanni, visitors would arrive in Kilinochchi. Once a lackluster hub of a poor agricultural district, little more than a stop on the road or train to and from Jaffna, Kilinochchi had become an illustrious site. Many eyes were focused on this acting capital of Tamil Eelam, where the LTTE unfolded its state apparatus. One impressive building decorated with signposts and flags followed upon another. Lining the road were the Tamil Eelam court (Tamil Eela Nithimandram), then the police headquarters (Kaval Thalamaiyakam), the political wing (Arasiyal Peerivu), a human rights secretariat (Manitha Urimai Seyalagam), and other offices. It was clear that this institutional display catered to international eyes, and it would be naïve to think that foreign visitors were external to this dramaturgy. ${ }^{4}$ Many visitors reproduced the significance of these mushrooming institutions with quick snapshots outside before joining the performative action in meetings with the officers within. Aid workers coordinated their projects with LTTE officials, and academics interviewed them about the governing logic of Tamil Eelam. Some prided themselves on having met Tamilselvan, a senior cadre who headed the political wing. They could only dream of meeting the LTTE's leader, Prabhakaran, since he rarely met foreigners other than Norwegian peace negotiators.

While Prabhakaran never left his territory, Tamilselvan travelled to the ends of the world during this period; in support of the ceasefire and peace talks, a range of European governments enabled and encouraged him and his team to visit capital after capital. Most foreign ministries were reluctant to host them officially, and so opted for a less direct engagement, such as setting up meetings or roundtables hosted by non-official entities. The Dutch Ministry of Foreign Affairs, for example, used the Clingendael Institute, a foreign policy think-tank in The Hague where Bart worked at the time, to create an interface with no formal status. LTTE delegations quickly learned diplomatic protocols. It was obvious that some of their members were still getting used to wearing suits and walking around in seventeenth-century manors, but they soon developed a routine. A constellation of representatives of several newly created LTTE institutions added gravitas to Tamilselvan's entourage. That he worked with a translator (though he seemed to understand English very well) added a layer of dignity. Many of his hosts later undertook countervisits to Kilinochchi, where they were lodged in the LTTE hotel while visiting different offices during the day. Their arrivals, meetings, greetings, and departures were all accompanied by great pomp, and photos of senior cadres shaking hands with important looking Europeans quickly piled up.

\footnotetext{
4 The heated debate between Stokke (2006) and Sarvananthan (2007) bears testimony to this.
} 
The institutional landscape of Tamil Eelam was more complicated than the offices lining up along Kilinochchi's main road suggested. The more interesting politics occurred in the institutions where the boundaries were deliberately blurred. These were entities that straddled the LTTE and its supposed others so as to serve as ambiguous buffers around the movement vis-à-vis the Sri Lankan government and international actors. For instance, the Tamils Rehabilitation Organization (TRO), with its key office in Kilinochchi, was known to be an appendage of the LTTE, but presented itself as an international nongovernmental organization. This framing was convenient for the LTTE since it provided an access channel to donors and buttressed the impression that they were tolerant enough to countenance something resembling a civil society. It was also convenient for some donors because it enabled them to engage in development work in LTTE-controlled areas (dearly needed from a poverty perspective and considered helpful in transforming the LTTE into a less authoritarian actor) without directly entering into a financial relationship with the LTTE, which would have been politically untenable, and illegal for donor agencies under governments that had proscribed the movement.

This practice of using buffer institutions to blur the lines around the LTTE was followed by large parts of the Sri Lankan civil service in the northeast of the island. As we have described elsewhere (Klem 2012; Klem and Maunaguru n.d.; see also Stokke 2006), many Tamil administrators of government institutions, as well as health personnel and teachers, continued to function in LTTEcontrolled territory and thereby served both the Sri Lankan state and the insurgent counter-state. The presence of state entities clearly contradicted the LTTE's staunch assertions that it wanted a separate state, but these government personnel were Tamil, and they generally complied with LTTE rules, enjoyed a level of legitimacy, and provided indispensable skills and some government funding. The Sri Lankan government did not cut these officers off because that might have been interpreted as an acknowledgement that these territories had seceded. Keeping a foot in the door with government institutions and aid packages was a way to show both local people and outsiders that the state cared for its people.

The LTTE's institutional outfit was thus enacted through a highly convoluted political landscape of competing sovereign claims. Contrary to its rhetoric of purity, loyalty, and unquestioned supremacy, the movement declined to weed out such hybrid forms and fragmented institutions. Instead, it engaged in what we may call "sovereign encroachment": a gradual process of working out hegemony over the public sphere by experimenting and redrawing boundaries. ${ }^{5} \mathrm{At}$ the same time, it is clear that this encroachment was ultimately geared toward consolidating exclusive territorial and institutional control. When the peace

\footnotetext{
5 We discuss the idea of sovereign encroachment in more detail in Klem and Maunaguru n.d.
} 
process and the ceasefire collapsed in 2006 and the government's military offensive started to make major inroads into LTTE territory, the movement did not revert to a guerrilla strategy of melting away into the jungle. It instead fought a symmetrical war, trying to hold front lines with large defense bunds and mine fields while forcing a large number of civilians to go with them in their retreat (De Silva-Ranasinghe 2010). This strategy was entirely in synch with the mirage of territorialized sovereignty, but it proved unsustainable against an army with massively increased firepower and led by a government undeterred by high civilian casualties, no matter the political costs.

In sum, the LTTE established an elaborate entourage of governance institutions around an unmitigated military core. Some of these mimicked the Sri Lankan state. Their offices, signs, administrative forms, and uniforms, their protocol for official exchange, even the checkpoints can all be seen as replications. It is clear that their ambition was to perform, not just an exact duplicate, but a superior variant: a South Asian repertoire of order and authority that was more efficient and righteous than the Sri Lankan state, and above all else, fully devoted and incorruptible. Other institutions comprised hybrid forms: entities that had already existed that were partly co-opted by the insurgency. Obvious examples include the proxy rule though government civil servants, doctors, and teachers, as well as buffer institutions like the Tamils Rehabilitation Organization. Through a drawn-out process of testing, moving, blurring, and entrenching boundaries and institutions, the insurgents ultimately sought to enact two divisions: between themselves and the society they claimed to rule, and between Tamil Eelam and Sri Lanka. These divisions crystallized into a visual display, for both internal and external audiences, of the LTTE as a sovereign actor.

\section{RETHINKING REBEL GOVERNANCE}

We are not the first to be fascinated by the way insurgent rulers enact forms of order. There is an impressive and growing body of work on insurgencies - their diverse political economies, sociological make-ups, ideological outlooks, approaches to mobilization and recruitment, military strategies, relations with (paramilitaries of) rival or patron states, cultural and gendered agendas, and so on (key contributions include Jentzsch, Kalyvas, and Schubiger 2015; Kalyvas 2006; 2008; Sanín and Wood 2014; Staniland 2012; 2014; Weinstein 2007; Wood 2008; 2009).

Building on this broader scholarship is a literature focused on rebel governance and interpreting rebel movements as embryonic forms of state building (Arjona 2014; Arjona, Kasfir, and Mampilly 2015; Caspersen 2012; Mampilly 2011). This scholarship interrogates the tendency to conceive of rebel movements as anomalous warlords in anarchic environments, and explores how insurgent movements seek to rule people and territory by adopting the three 
classical tenets of a state. These are, in order of insurgent priority, security, welfare, and representation. These form the basis of a social contract that warrants rebels to enforce discipline, taxation, and recruitment. In short, this literature holds that the differences between rebel movements - in their contexts, the nature of their adversary, their resource base, their ideological orientation, and their internal organization - account for the extent to which they develop institutional governance. That, in turn, helps explain different patterns of violence and longer-term political outcomes, in that rebels who construct elaborate governance are less likely to engage in rampant, indiscriminate violence.

The institutional rule of the LTTE resonates well with this literature. The movement sits at one end of the spectrum elaborated by these authors - high levels of institutionalism matched with largely disciplined use of violenceand this made sense given the opportunity structure around the movement. Mampilly (2011) provides an apt overview regarding the history of state penetration (people's expectations of state services were relatively high); limited availability of profitable natural resources (LTTE needed the taxes); the movement's secessionist outlook (institutions were part of the end goal); periods of relative calm (the ceasefire enabled institutional expansion); and the presence of international aid (the movement was able to co-opt and coordinate resources and services). In a similar vein, Elisabeth Wood (2009) observes that the LTTE, despite its violent character and in contradiction to many other armed movements, by and large refrained from sexual violence due its puritanical cultural outlook and the strictly enforced moral code of its cadres. This matches with theorization of the LTTE as a movement with a well-embedded social base and closely integrated horizontal and vertical ties (Staniland 2014: 141-77).

The literature we have cited engages with some of the central conundrums of sovereignty, but includes little explicit discussion of the meaning and implications of the concept. The literature on rebel governance as an institutionalized social contract, in particular, tends to adopt sovereignty as a loose synonym for state governance, in terms of violence, order, services, and representation. ${ }^{6}$ All of this makes good sense, but it reifies a particular kind of sense: the logic of governance and discipline. The fascinating thing about rebel movements like the LTTE, however, is that part of their violent legitimacy and authority escapes the transactional calculus of exchanging services for loyalty.

Indeed, one reason the LTTE's institutional charade captivated its subjects was not so much that order had been normalized, but rather the opposite: the enactment of this order caught the eye because it was inherently transgressive. What could have been a mere parody, with "the boys" dressing up like a state, was instead a performance that came to seem real. They acted like statesmen

\footnotetext{
${ }^{6}$ See, for example, Mampilly's discussion of "de facto," "empirical," or "counter-state" sovereignty (2011: 39, 49-50), and Caspersen's discussion of "internal sovereignty" and "external sovereignty" (2012: 102-22).
} 
and mingled with diplomats in offices, embassies, and European manors, and their charade was not exposed! It was stunning precisely because its purportedly normal institutional behavior was in fact quite abnormal. Moreover, the performance of orderly rule was sometimes subjected to sudden changes of script. Despite the dressing up of police and courts, there was something uncanny about their law: the rules could change, heroes could be declared enemies, and violence could be deployed in unforeseeable ways. Sovereign practices, indeed, but less in the sense of rules and discipline and more in the sense of an unfathomable sovereign who is capable of unleashing excessive violence.

This is why the literature on the sovereign paradox, sublime violence, and divine kingship has much to offer toward elucidating the LTTE case. Surprisingly, there has been little engagement between this scholarship and the rebel governance literature, but marshalling both together can help us understand movements like the LTTE. The vernacular understanding of the movement was clearly not limited to the world of offices, penal codes, recruitment, and taxation. The LTTE's repertoire of bureaucratic order in pursuit of separatism was complemented by a very different repertoire: an elaborate register of idolatry around heroism, cosmic leadership, and glorified death.

\section{LTTE RULE AS CAPRICIOUS TRANSCENDENTAL AUTHORITY}

LTTE cadres instilled both awe and fear. Unlike the LTTE's Kilinochchi offices, where the movement's institutional apparatus was on display, crucial aspects of the movement's activities were deliberately kept secret and invisible. One could never be sure where the LTTE's tentacles would reach, where its cadres were, and what they were up to, or what they could see and hear. Nor could one be sure what would happen to people who were arrested for disloyalty or breaking rules. ${ }^{7}$ Despite the presence of court buildings, people remained well aware of and apprehensive about the disappearances, excessive violence, and other brutish ways in which the movement dealt with dissent.

At the same time, people were fascinated by LTTE cadres. Others have described how their public persona was closely tied up with commitment and purity, manifest in mundane behaviors like abstinence from alcohol and sex, as well as in sacrifice and suicide. LTTE fighters enacted "violent devotion" (Hellmann-Rajanayagam 1994a; 2005; Schalk 1997a; Thiranagama 2011; Trawick 2007). They were known to wear a cyanide capsule on a necklace (kuppi) at all times to avoid being captured alive. Sacrificing their lives would prevent their giving up intelligence, but the capsules also served as icons of commitment and were useful for propaganda purposes. Within the LTTE narrative of valor, a special place was reserved for cadres who had

\footnotetext{
7 See Sharika Thiranagama's work on cultural intimacy in connection to heroes and traitors, discussed earlier $(2010 ; 2011)$.
} 
killed themselves. These Black Tigers (karum pullikal) took the notion of sacrifice to a different level. Not only did they abandon their lives while fighting for the cause, but they transformed themselves into human bombs, their bodies themselves became weapons against the enemy.

These expressions of commitment can be interpreted as culturally coded citations from a South Asian historical mythology of struggle. The exact nature of these citations has spawned significant academic debate. Roberts (1996; 2014) and Trawick (2007) have interpreted the LTTE's repertoire of warriors (maravar), great heroes (mavirar), and martyrs (tiyaki, those who abandon life) as a cultural extension of an ancient history of worship, devotion, and sacrifice, from the Bhakti tradition in particular. ${ }^{8} \mathrm{~A}$ finer-grained historical perspective holds that this sacralized devotion should be seen as an indirect citation that borrowed from modern repertoires that, in turn, sought to revive precolonial Hindu practice. Schalk suggests the LTTE adopted concepts from both India's anticolonial struggle and South India's Dravidian movement (1997a; 1997b). Its leader Prabhakaran was particularly inspired by the Indian nationalist leader Subhas Chandra Bose (1897-1945), who had adapted ideas of personalized power and sacrifice from early twentieth-century European militant movements to the Indian context. The LTTE also drew from the Dravidian movement that came to fruition in South India in late colonial and postcolonial times. This movement was at loggerheads with Bose's panIndian ideals since it agitated against a united India dominated by the north. The Dravidian struggle was centered around resistance to Brahmin caste hierarchy and the Hindi language, both seen as northern impositions, and attempted to reinstate a glorified South Indian past of Tamil kingdoms, mainly from the Sangham and Chola periods.

Several decades later, the LTTE leadership revived this program of celebrating the ancient history of the Tamils, purifying Tamil language and culture, and honoring its poetry and literature. In adopting these forms for the northeast Sri Lankan context, however, some elements were left out or reinterpreted, and new ones were added. For example, there was slippage between ethnicity and caste in the LTTE's adoption of Dravidian ideas: they replaced the struggle against Brahmin dominance with an agenda of uniting Tamil castes in the struggle against Sinhalese dominance. Rather than historical continuity and cultural determinacy, what we find is a more contingent outcome of a longer citational sequence of selective historical interpretation and adaptation. The LTTE borrowed from Indian anticolonialism and Dravidian nationalism, which had themselves drawn from still older cultural repertoires. The LTTE's martyrology was a bricolage of concepts selected from diverse backgrounds.

\footnotetext{
8 The Bhakti movement was a Hindu movement focused on aspiring to divinity through personal devotion. It originated in Tamil Nadu in the sixth century CE before spreading across the subcontinent.
} 
The figure of the tiger itself can be seen as a citation of the Chola flag, but the movement used biological metaphor to embed this animate figure in a modern guerrilla, with the famous phrase, "The thirst of the tigers is Tamil Eelam." Nonviolent Ghandian methods like fasting to death were deployed alongside martial aggression. Socialist lingo of class justice was put to ethno-nationalist use. Masculine forms of heroism were transformed into female martiality. A purportedly secular ideology of nationalism and emancipation ${ }^{9}$ rubbed shoulders with religious rituals of devotion and sacrifice. Within that, Hindu iconic practice was seamlessly combined with Christian practices such as martyr cemeteries and admiration for selected Christian elite politicians such as SJV Chelvanayakam (Schalk 1997a; 1997b).

Drawing on these different registers, the LTTE generated an elaborate output of texts, poetry, broadcast, and performances glorifying its fighters (Hellmann-Rajanayagam 2005; Schalk 1997a; Thiranagama 2011; Trawick 2007). All cadres who had died in combat were commemorated as heroes during an annual martyrs' day (mavirar nal). During the later period of the LTTE these celebrations became elaborate ceremonial events held in the areas under LTTE control and also in Sri Lankan Tamil diaspora communities. Lamps were lit atop each tombstone in the movement's impressive war cemeteries. These burial grounds became the territorial cornerstones of Tamil Eelam, a direct link between martyrdom and the soil of the homeland (Natali 2008; Schalk 1997a). Elaborate rituals with processions were staged in mourning of those who had given their lives for the cause. In the LTTE's repertoire of martyrdom, these cadres had attained vera maranam, a death of valor, and they earned a form of immortality by becoming kaval theivankal, the protecting gods of Tamil Eelam. It is significant that cadres who died in accidents were not commemorated in this way, nor were fighters of rival Tamil movements killed in combat, even if they had arguably contributed to the Tamil cause. Only cadres who had died for the LTTE deserve such honors. More specifically, only those who died for its leader Prabhakaran could be immortalized as martyrs.

Conversely, those who betrayed Prabhakaran were not merely disciplined, but faced ruthless excess, and the sheer force of Prabhakaran's anger so expressed rippled throughout Tamil society. The LTTE experienced several difficult moments when a high-ranking cadre broke away and caused fissures in the movement. This happened in the mid-1990s with Mahattaya and in the mid-2000s with Karuna, both well-known leaders extolled for their courage, commitment, and military ability. Mahattaya was known to be a close friend of Prabhakaran, and the allegation that he was collaborating with the Indian

\footnotetext{
9 The memoirs of LTTE "ideologue" Anton Balasingham (2004) articulate the keywords of this secular narrative of separatism and social revolution: Tamil homeland, self-determination, state oppression, national liberation struggle, and social emancipation.
} 
secret service to assassinate the leader caused a brief rupture followed by his capture and execution (Hellmann-Rajanayagam 1994a). In 2004, Karuna was accused of treason and told to report to the leader. Fearing a fate similar to Mahattaya's, the eastern commander broke away with a large number of cadres, which resulted in an intense military confrontation. Karuna's forces were defeated with surprising efficiency and he took refuge with the government (Sánchez Meertens 2013). In both cases, perceived traitors were met with sovereign violence. There was a disciplinary element to this, but it had to do less with the measured force of court proceedings than with the violent excess of a tormented sovereign setting the record straight by employing sublime violence to cleanse the realm of traitors.

Though people would at times refer to Prabhakaran as thampi or annan (younger/older brother), in line with the movement's self-image as a form of kinship, he was most commonly called thalaivar (leader). LTTE propaganda portrayed him as a great hero who had displayed his boldness, courage, cunning, and skill on countless occasions. Stories circulated about how he had overcome unimaginable difficulties and songs about him as an immortal super-human were played on the LTTE TV station Nitharasam and through loudspeakers on the streets. These stories percolated through journalistic and popular academic writings about the movement. Narayan Swamy's books on the movement (Tigers of Lanka, 1994) and on Prabhakaran (Inside an Elusive Mind, 2003) are cases in point. They reify the cult around the movement and its leader. The latter book entered our research in an unexpected way during an interview in the Kilinochchi office of the LTTE's women's wing (Suthanthirapparavaigal, or "Birds of Freedom"). To our surprise, one senior cadre picked the book from her shelf to show it to us. She was clearly amazed that Prabhakaran was now emerging on a global stage, with international authors trying to comprehend his ungraspable genius.

But the LTTE's adulation of Prabhakaran went beyond his heroic and visionary leadership - it inserted its leader into the pantheon as a suriya thevan, or sun god. Both the textual and the visual idolatry around Prabhakaran reified him as a divine figure with the potency required to foresee, and protect and nurture, the future of the Tamil nation. In this way his persona resembled the figure of a Hindu deity. ${ }^{10}$ Many of these deities are able to take human (or other animate) form to help their followers. They are both human and divine, both embedded as agents within the community and elevated above it. They

\footnotetext{
10 This observation resonates with Heesterman's (1985) work on Vedic notions of sovereignty and Gilmartin's $(2012 ; 2015)$ interpretation of these notions as antecedents to contemporary forms of sovereignty. Again, though, we do not see the LTTE's sovereign experiment as a direct citation of ancient Hindu practices, but instead place it in a sequence with modern anticolonial expressions of power, sacrifice, legitimacy, and charisma, which in turn reinterpreted precolonial traditions.
} 
are both proximate and distant, closely affiliated and yet difficult to reach out to.

Prabhakaran was difficult for even LTTE cadres to access, let alone ordinary people. There was no identifiable headquarters where an audience could be requested, and one was never sure when, where, and whether he would publicly reveal himself. One had to earn the privilege of seeing Prabhakaran. Suicide cadres were special in this regard. It was said that he would visit training camps for Black Tigers. More significantly, these suicide cadres would eat a last supper with Prabhakaran before being sent on their mission, a rite of passage across the boundary between life and death. Becoming a protective god by dying for the leader of the Tamil cause was a way to be with Prabhakaran forever.

Within the broad story of LTTE sovereignty, then, we find the more specific story of Prabhakaran as a sovereign figure. He came to be seen as the embodiment of Tamil Eelam. To question him was to question the cause; betrayal of him betrayed the Tamil people. Indeed, Prabhakaran's physical wellbeing and appearance were seen to denote the state of the nation. He was normally portrayed with a moustache and in military uniform, a belted gun on his hip, a warrior-like display associated with war. During the peace talks of 2002-2004, however, he was sometimes depicted with moustache shaven and dressed in clothes resembling Indian court dress, with bodyguards in concurrent uniforms. This civilian outfit displayed a South Asian kind of authority that was explicitly contrasted with the Sri Lankan state and was seen to symbolize the prospect of peace. His body, too, was bound to the nation's fate, and he famously had instructed his bodyguards to kill him the moment he betrayed the cause of Tamil Eelam. Prabhakaran's ability to evade death was central to his public persona, but if he did die it would represent the passing of not just a leader, but of a sovereign body and of Tamil Eelam itself. It is this embodiment that was shattered when the Sri Lankan government circulated pictures of Prabhakaran's mutilated corpse in the culmination of the LTTE's military defeat in May of 2009. And it is in this light that we would place the circulating claims that the pictures had been forged, and the nearmessianic speculations that Prabhakaran remained at large.

\section{ENGAGING THE SOVEREIGN PARADOX WITH MIMICRY}

Summing up, the LTTE's pursuit of sovereign rule encompassed two paradoxical repertoires of power: the enactment of orderly governance backed by disciplinary violence, and the capricious rule of an ungraspable movement with a mythical leader capable of deploying sublime violence. Sovereignty requires the political vigor to rewrite the rules of the game in a way that yields to no higher authority, to claim supremacy by redefining what the orderly, righteous, and normal entail. Because of this, to rule as a sovereign demands the paradoxical quality of embodying both the foundation of legitimate order and the 
capacity to strike and to overthrow the routine, the potency to both nurture and disregard human life. In synch with Gilmartin's (2015) and Heesterman's (1985) writing on the irresolvable paradox of sovereignty, the LTTE offered its subjects an elevated beacon of unity and meaning, but also harbored an unbounded force of death, destruction, and misery. It enabled and protected life and gave it meaning, but it could also take life away.

Conceiving of sovereignty as citational practice provides insights for grappling with this paradox. Parts of the LTTE's sovereign effort consisted of mimicking its main adversary; its offices, uniforms, letterheads, and signboards were clearly premised on the institutional architecture of Sri Lanka's postcolonial state. Adopting the trappings of the civil service helped the movement to enact an order that people recognized as useful and legitimate, but which was also subtly different. Yet the LTTE did not borrow its institutional forms only from the Sri Lankan civil service, but also from displays of orderly authority elsewhere (as evident in the LTTE customs uniforms and Prabhakaran's civilian outfit). The movement's elaborate cult of martyrdom and sacrifice adopted and reinterpreted elements from the Indian anticolonial struggle and the Dravidian nationalist movement. In doing so, it mixed a range of religious rituals with secular outlooks to create a modern Sri Lankan Tamil repertoire of public celebration around the violent devotion of LTTE fighters. The portrayal of Prabhakaran as a sun god through songs, pictures, and rituals replicated common religious and political symbology, united in the thalaivar figure: the leader as the ultimate referent of the entire repertoire. In short, the LTTE's sovereign mimicry drew from a range of discursive registers and intervened in more than one kind of citational cycle.

Mimicry does not simply duplicate. Rather, it produces a copy that is not quite the same and because of that, as Bhabha's (1994) work underscores, it is capable of unsettling, reshaping, or even mocking that which is being mimicked. Mimicry is not just a matter of vying for authenticity; it also opens up space to question or redefine authenticity. The LTTE engaged in state mimicry, but in doing so produced innovations, forms of slippage, and unforeseen outcomes. Their performance of sovereignty not only rendered the movement legible as a sovereign formation in an idiom that their subjects were familiar with, but also reconfigured the idiom, thus affecting their subjects' understandings and expectations of sovereignty. It established new linkages between religious symbols and political authority, facilitated the Dravidian nostalgia for a glorious past to take root in Sri Lanka, and instilled a narrative of violent devotion that outlived the bulldozing of LTTE cemeteries. It made thinkable a South Asian form of order that differed from, and unsettled, the depiction of Sri Lanka's postcolonial state as natural, inevitable, and legitimate.

The LTTE's elaborate poetry and imagery left a discursive legacy in the lexicon of Tamil politics and among audiences beyond Sri Lanka. Most obviously, it captivated the minds of many diaspora Tamils (Fuglerud 2009: 206-9). 
Within that discursive legacy, LTTE leader Prabhakaran remains a central reference point. As an exalted persona with divine qualities and an uncompromising determination, a fearless leader and a ruthless enforcer of loyalty, the sovereign figure of Prabhakaran lives on in the Tamil political consciousness. In Sri Lanka's Tamil community as well as in diaspora and, importantly, in the adjacent Indian state of Tamil Nadu, he remains a political signifier. References to his person, body, and speech can act as markers of devotion to a Tamil political struggle that transcends petty politics. Because of Prabhakaran's elevation above the tussles of everyday politics, rival Tamil leaders elbow each other claiming to be his political heir while painting their opponents as traitors to his cause. Ironically, this subjects Prabhakaran's relentless sovereign figure to the same petty politics that it is supposedly defined against. Conversely, for LTTE Sinhala nationalists Prabhakaran is a signifier of continued threats to Sri Lankan sovereignty, shorthand for the lurking dangers of terrorism. He is the emblem used to distinguish legitimate voices of Tamil grievances and concerns from illegitimate proponents of separatism.

Perhaps the clearest legacy of the LTTE's sovereign experiment lies in the firmly established demarcations of a Tamil nation: its territory, its cultural conduct, and the deeply embattled subject categories of heroes and traitors, insiders and outsiders, which define boundaries within Sri Lanka's fractured body politic. LTTE violence against the Muslims has left a deep rift between the Tamil and Muslim communities. Both groups speak the Tamil language and they used to be closely integrated in the northeast, but now the very idea of a common political project has become untenable. The LTTE's sovereign experiment was not alone responsible for these outcomes, and none of this is likely to remain static, but the movement's sovereign articulations have clearly marked, if not scarred the Sri Lankan Tamil community for years to come.

COMPARATIVE PERSPECTIVES ON SOVEREIGN ARTICULATION

The idea of sovereignty as citational practice among both aspirants to it and established states opens up productive space in which to think comparatively. If there is no sovereign gold standard to refer to, but only a ceaseless proliferation of sovereign forms through mimicry and mutation, then what we find is an endless sequence of near duplicates: similar, but not quite the same. What then can we learn from their similarities and differences? We cannot explore this in detail here, but in closing we will schematically identify two comparative perspectives that we think warrant attention, one historical, the other thematic.

If we think of the LTTE as a specifically South Asian articulation of sovereignty then a range of interesting parallels emerge with earlier sovereign endeavors on the subcontinent. We have seen that South Asia's history is not one of an untrammeled rise of the sovereign states, but instead a much more 
contingent and multifarious trajectory of encounter and contestation through which sovereign claims were rearticulated, boundaries redrawn, and subject categories redefined (salient references include: Beverley 2013; Gilmartin 2015; Moffat 2013; 2016; Moin 2015; Mongia 2007; Mukherjee 2010; Pinney 2011; Purushotham 2015). The LTTE's selective borrowing from both Subhas Chandra Bose's anti-colonialism and Dravidian nationalism in pursuit of Sri Lankan Tamil separatism is but one among many citational sequences. What might a more systematic historical assessment of South Asia's pedigree of sovereign formations elucidate? Many practices suggest historical continuity: the violent crafting of boundaries and subjects; the creative deployment of governing institutions on the fringes of state control; the importance attributed to visionary heroes, relentless devotion, and martyrdom; and the tensions between the procedural, institutional trappings of sovereign rule and the ungraspable categories used to legitimize them. ${ }^{11}$ These similarities are matched by some equally important differences in temporal context, such as increased, globalized circulation and the crystallized foundations of state sovereignty in South Asia. The region clings to the geopolitical order of sovereign nation-states, for it well knows the mayhem and brutality that can be released by attempts to redraw it. The excesses of the Partition, of violent attempts to purify the nation, and of insurrections aimed at overthrowing this order are within the living memories of many South Asians. The appetite for fundamental redefinitions of sovereignty is thus limited, and yet the citational cycle of sovereign rule, and the inherent contradictions that underlie it, have clearly not come to a standstill. Our preliminary observations here merit a systematic exploration of South Asia's contemporary insurgencies in relation to the region's turbulent history of working out sovereign rule.

While the LTTE's articulation of sovereignty has clear South Asian antecedents, the basic phenomenon of insurgents engaging in sovereign mimicry is not unique to the region. Thematically, we suggest there is scope for a comparative political theology of insurgent rule. Building on the existing comparative literature on insurgency, which raises questions regarding ideology, legitimacy, and leadership (Sanín and Wood 2014; Staniland 2014; Wood 2008), such a project would focus on the interplay between the religious and political elements of rebel rule. This would require closer scrutiny of the sovereign mimicry of rebel movements, including both their enactment of modern institutional governance (studied so well in the existing rebel governance literature) and the correlative register of elusive leadership, cults of sacrifice, and capricious violence.

11 Politicians, revolutionaries, and insurgents who draw on these historical precedents typically engage in some measure of reinterpretation. See, for example, Moffat's fascinating work on the postcolonial reconstructions of the life, death, and written legacies of the Indian revolutionary Bhagat Singh after his execution in 1931 (2013; 2016). 
One obvious case that comes to mind is that of Sendero Luminoso, the demised insurgency in Peru. Carlos Iván Degregori’s (2012) work on that movement describes a form of citational practice that shares much with that of the LTTE. Sendero Luminoso eclectically combined science, communism, and Catholicism. Its propaganda straddled reasoned logic, poetry, and a cult of death. Degregori portrays the movement's leader Guzmán as a "cosmocrat": simultaneously an oracle, a man of reason, and a supremo who inflicted violence on enemies, subjects, and cadres alike. It is easy to recognize similarities between Guzmán and Prabhakaran.

The parallels between Sendero Luminoso and the LTTE (and their leaders) raise interesting questions about the political theology of other insurgent groups. Movements like the Maoists in Nepal or the Moro insurgency in Mindanao, to name just two examples, are often readily classified as communist revolutionaries and Islamic separatists, respectively. A political theology perspective would help to debunk such easy secular-religious categories. After all, it is unlikely that any purely secular claim on sovereignty would have gained traction in Nepal, with its convoluted history of socio-religious exegesis, Hindu-monarchic rule, and democratic experiments. It is equally doubtful that an Islamic legitimation of insurgent rule in the Philippines would be able to insulate itself from the many nontheological symbolic forms, governing logics, and institutional practices that prevail in the archipelago. These are just two examples, but there are many contemporary insurgencies that could be examined and compared in these terms.

\section{CONCLUSIONS}

At the heart of sovereign practice lies the paradox between the systematic tenets of rule and the transcendental repertoire of symbolic power and sublime violence. Both dimensions were integral to the LTTE insurgency. The movement enacted a form of orderly governance backed by its ability to exercise violent discipline. At the same time, it preserved the cult of a surreptitious and ungraspable movement with a capricious god-like leader. We have made three conceptual points to come to grips with this paradox. First, we conceive of sovereign performance as citational practice, as an ever-evolving sequence of mimicries, each producing a near duplicate with slight alterations. Second, the exercise of violent discipline and the ability to both make and break the law is central to the sovereign endeavor. Finally, we have engaged with the literature on divine kingship to highlight both the political and the religious dimensions of sovereign rule, and also the associated tension between the profane and the sublime. Sovereignty, we assert, is a form of citational practice that involves diverse idioms of power and harbors the potency of both disciplinary and sublime violence.

Conceptualized in this way, sovereignty provides us with a lens that does not automatically gravitate toward the normative trappings of the modern, secular, liberal state of the classic European model. It helps us reach beyond 
normative categories like "freedom fighters" and "terrorists" that only obscure our understandings of insurgent movements. Irrespective of their success in securing international recognition, these organizations can usefully be thought of as laboratories of sovereignty, as nodes in the mutation of sovereign knowledge and practice. They combine, invent, and redefine narratives of power, and as such they influence the "frame" that sovereignty is.

In doing so, sovereign aspirants spawn questions about how sovereignty is composed from multiple registers of authority, legitimacy, symbolism, and cultural conduct. They remind us that sovereignty encompasses both disciplinary violence (the ability to preserve order) and sublime violence (the ability to inflict horror). Despite their elevated repertoire of liberal institutions, recognized democratic states, too, embody capricious capacities. In South Asia, the violent memories of sovereign assertion during and after colonialism continue to shape the political landscape, the entrenchment of subject categories, and the awe of state power. On a global level, the potency of state militaries and intelligence-omnipresent surveillance, drone strikes, and the cruelties of off-the-grid detention-bears testimony to the sublime capacities of modern states. These practices are steeped in a heavily securitized narrative of protecting the civilized world against evil, but they have spectacular performative qualities as well. And for many state subjects, not least in South Asia, they represent an intractable potency to strike. While sovereigns provide protection and welfare to their subjects, one can never be entirely certain about their benignity. Not unlike the descriptions in the Sanskrit texts studied by Heesterman (1985), the same king who protects his people may turn around and devour them.

\section{REFERENCES}

Abeles, Marc. 1988. Modern Political Ritual: Ethnography of an Inauguration and a Pilgrimage by President Mitterrand. Current Anthropology 29, 3: 391-404.

Agamben, Giorgio. 2005. State of Exception. Chicago: University of Chicago Press.

Arjona, Ana. 2014. Wartime Institutions: A Research Agenda. Journal of Conflict Resolution 58: 1390-418.

Arjona, Ana, Nelson Kasfir, and Zachariah Mampilly, eds. 2015. Rebel Governance in Civil War. Cambridge: Cambridge University Press.

Balasingham, Anton. 2004. War and Peace: Armed Struggle and Peace Efforts of Liberation Tigers. Mitcham: Fairmax Publishing.

Bartelson, Jens. 1995. A Genealogy of Sovereignty. Cambridge: Cambridge University Press.

Beverley, Eric L. 2013. Frontier as Resource: Law, Crime, and Sovereignty on the Margins of Empire. Comparative Studies in Society and History 55, 2: 241-72.

Bhabha, Homi. 1994. The Location of Culture. London: Routledge.

Brun, Cathrine. 2008. Birds of Freedom. Critical Asian Studies 40, 3: 399-422.

Burghart, Richard. 1996. The Conditions of Listening: Essays on Religion, History and Politics in South Asia. New Delhi: Oxford University Press.

Caspersen, Nina. 2012. Unrecognized States: The Struggle for Sovereignty in the Modern International System. Cambridge: Polity Press. 
Degregori, Carlos. 2012. How Difficult It Is to Be God: Shining Path's Politics of War in Peru, 1980-1999. Madison: University of Wisconsin Press.

De Silva-Ranasinghe, Sergei. 2010. Strategic Analysis of Sri Lankan Military's CounterInsurgency Operations, Strategic Analysis Paper. West Perth: Future Directions International.

Fuglerud, Øivind. 2009. Fractured Sovereignty: The LTTE's State-Building in an InterConnected World. In Cathrine Brun and Tariq Jazeel, eds., Spatialising Politics: Culture and Geography in Post-Colonial Sri Lanka. London: Sage, 194-215.

Geertz, Clifford. 1980. Negara: The Theatre State in Nineteenth-Century Bali. Princeton: Princeton University Press.

Gilmartin, David. 2012. Towards a Global History of Voting: Sovereignty, the Diffusion of Ideas, and the Enchanted Individual. Religions 3: 407-23.

Gilmartin, David. 2015. Rethinking the Public through the Lens of Sovereignty. South Asia: Journal of South Asian Studies 38, 3: 371-86.

Hansen, Thomas B. 2001. Governance and the Myths of State in Mumbai. In C. J. Fuller and Véronique Bénéï, eds., The Everyday State and Society in Modern India. New Delhi: Social Science Press, 31-67.

Hansen, Thomas B. and Finn Stepputat, eds. 2005. Sovereign Bodies: Citizens, Migrants, and States in the Postcolonial World. Princeton: Princeton University Press.

Hansen, Thomas B. and Finn Stepputat. 2006. Sovereignty Revisited. Annual Review of Anthropology 35: 295-315.

Hasbullah, Shahul. 2001. Muslim Refugees: The Forgotten People in Sri Lanka's Ethnic Conflict. Research and Action Forum for Social Development, Nuraicholai, Sri Lanka.

Heesterman, J. C. 1985. The Inner Conflict of Tradition: Essays in Indian Ritual, Kingship and Society. Chicago: University of Chicago Press.

Hellmann-Rajanayagam, Dagmar. 1994a. The Tamil Tigers: Armed Struggle for Identity. Stuttgart: Franz Steiner Verlag.

Hellmann-Rajanayagam, Dagmar. 1994b. The "Groups" and the Rise of Militant Secessionism. In Chelvadurai Manogaran and Bryan Pfaffenberger, eds., The Sri Lankan Tamils: Ethnicity and Identity. Boulder: Westview Press, 168-207.

Hellmann-Rajanayagam, Dagmar. 2005. And Heroes Die: Poetry of the Tamil Liberation Movement in Northern Sri Lanka. South Asia: Journal of South Asian Studies 28, 1: 112-53.

Hocart, A. M. 1941 [1927]. Kingship. London: Watts \& Co.

Hoole, Rajan. 2001. Sri Lanka: The Arrogance of Power: Myths, Decadence and Murder. Colombo: University Teachers for Human Rights (Jaffna).

Jentzsch, Corinna, Stathis Kalyvas, and Livia Schubiger. 2015. Militias in Civil Wars. Journal of Conflict Resolution 59, 5: 755-69.

Kalyvas, Stathis. 2006. The Logic of Civil War. Cambridge: Cambridge University Press.

Kalyvas, Stathis. 2008. Ethnic Defection in Civil War. Comparative Political Studies 41, 8: 1043-68.

Kantorowicz, Ernst. 1997 [1957]. The King's Two Bodies: A Study in Mediaeval Political Theology. Princeton: Princeton University Press.

Klem, Bart. 2012. In the Eye of the Storm: Sri Lanka's Front-Line Civil Servants in Transition. Development and Change 43, 3: 695-717.

Klem, Bart and Sidharthan Maunaguru. n.d. (forthcoming). Public Authority under Sovereign Encroachment: Leadership in Two Villages during Sri Lanka's War. Modern Asian Studies 52, 2 (2018). 
Korf, Benedikt, Michelle Engeler, and Tobias Hagmann. 2010. The Geography of Warscape. Third World Quarterly 31, 3: 385-99.

Mampilly, Zachariah. 2011. Rebel Rulers: Insurgent Governance and Civilian Life during War. Ithaca: Cornell University Press.

Maunaguru, Sitralega. 1995. Gendering Tamil Nationalism: The Construction of "Woman" in Projects of Protest and Control. In Pradeep Jeganathan and Qadri Ismail, eds., Unmaking the Nation: The Politics of Identity and History in Modern Sri Lanka. Colombo: Social Scientists' Association, 158-75.

Moffat, Chris. 2013. Experiments in Political Truth. Postcolonial Studies 16, 2: 185-201.

Moffat, Chris. 2016. Bhagat Singh's Corpse. South Asia: Journal of South Asian Studies 39, 3: 644-61.

Moin, Azfar A. 2015. Sovereign Violence: Temple Destruction in India and Shrine Desecration in Iran and Central Asia. Comparative Studies in Society and History 57, 2: 467-96.

Mongia, Radhika V. 2007. Historicizing State Sovereignty: Inequality and the Form of Equivalence. Comparative Studies in Society and History 49, 2: 384-411.

Moore, Mick. 1993. Thoroughly Modern Revolutionaries: The JVP in Sri Lanka. Modern Asian Studies 27, 3: 593-642.

Mukherjee, Mithi. 2010. India in the Shadow of Empire: A Legal and Political History, 1774-1950. Delhi: Oxford University Press.

Natali, Cristiana. 2008. Building Cemeteries, Constructing Identities: Funerary Practices and Nationalist Discourse among the Tamil Tigers of Sri Lanka. Contemporary South Asia 16, 3: 287-301.

Pinney, Christopher. 2011. The Tiger's Nature, but not the Tiger: Bal Gangadhar Tilak as Mohandas Karamchand Gandhi's Counter-Guru. Public Culture 23, 2: 395-416.

Purushotham, Sunil. 2015. Internal Violence: The "Police Action" in Hyderabad. Comparative Studies in Society and History 57, 2: 435-66.

Roberts, Michael. 1996. Filial Devotion in Tamil Culture and the Tiger Cult of Martyrdom. Contributions to Indian Sociology 30, 2: 245-72.

Roberts, Michael. 2014. Encompassing Empowerment in Ritual, War and Assassination. Social Analysis 58, 1: 88-106.

Sánchez Meertens, Ariel. 2013. Letters from Batticaloa: TMVP's Emergence and the Transformation of Conflict in Eastern Sri Lanka, PhD thesis, Utrecht University, The Netherlands.

Sanín, Francisco and Elisabeth Wood. 2014. Ideology in Civil War: Instrumental Adoption and Beyond. Journal of Peace Research 51, 2: 213-26.

Sarvananthan, Muttukrishna. 2007. In Pursuit of a Mythical State of Tamil Eelam: A Rejoinder to Kristian Stokke. Third World Quarterly 28, 6: 1185-95.

Schalk, Peter. 1997a. The Revival of Martyr Cults among Ilavar. Temenos 33: 151-190. At http://tamilnation.co/ideology/schalk01.htm (accessed 16 May 2016).

Schalk, Peter. 1997b. Historisation of the Martial Ideology of the Liberation Tigers of Tamil Ealam (LTTE). South Asia: Journal of South Asian Studies 20, 2: 35-72.

Schmitt, Carl. 2005 [1922]. Political Theology: Four Chapters on the Concept of Sovereignty. George Schwab, trans. Chicago: University of Chicago Press.

Singh, Bhrigupati. 2012. The Headless Horseman of Central India: Sovereignty at Varying Thresholds of Life. Cultural Anthropology 27, 2: 383-407.

Spencer, Jonathan. 2007. Anthropology, Politics and the State: Democracy and Violence in South Asia. Cambridge: Cambridge University Press.

Staniland, Paul. 2012. Organizing Insurgency: Networks, Resources and Rebellion in South Asia. International Security 37, 1: 142-77. 
Staniland, Paul. 2014. Networks of Rebellion: Explaining Insurgent Cohesion and Collapse. Ithaca: Cornell University Press.

Stengs, Irene. 2008. Modern Thai Encounters with the Sublime: The Powerful Presence of a Great King of Siam through His Portraits. Material Religion 4, 2: 160-71.

Stokke, Kristian. 2006. Building the Tamil Eelam State: Emerging State Institutions and Forms of Governance in LTTE-Controlled Areas in Sri Lanka. Third World Quarterly 28, 6: 1197-201.

Stokke, Kristian and Jayadeva Uyangoda, eds. 2011. Liberal Peace in Question: Politics of State and Market Reform in Sri Lanka. London: Anthem Press.

Swamy, Narayan M. R. 1994. Tigers of Lanka: From Boys to Guerrillas. Delhi: Konark Publishers.

Swamy, Narayan M. R. 2003. Inside an Elusive Mind: Prabhakran, the First Profile of the World's most Ruthless Guerrilla Leader. Delhi: Literate World.

Thiranagama, Sharika. 2010. In Praise of Traitors: Intimacy, Betrayal and the Sri Lankan Tamil Community. In Sharika Thiranagama and Tobias Kelly, eds., Traitors: Suspicion, Intimacy and the Ethics of State-Building. Philadelphia: University of Pennsylvania Press, 127-49.

Thiranagama, Sharika. 2011. In My Mother's House: Civil War in Sri Lanka. Philadelphia: University of Pennsylvania Press.

Trawick, Margaret. 2007. Enemy Lines: Warfare, Childhood, and Play in Batticaloa. Berkeley: University of California Press.

Walker, Robert. 1993. Inside/Outside: International Relations as Political Theory. Cambridge: Cambridge University Press.

Watson, C. W. 1997. "Born a Lady, Became a Princess, Died a Saint": The Reaction to the Death of Diana, Princess of Wales. Anthropology Today 13, 6: 3-7.

Weber, Cynthia. 1995. Simulating Sovereignty: Intervention, the State and Symbolic Exchange. Cambridge: Cambridge University Press.

Weber, Cynthia. 1998. Performative States. Millennium 27: 77-95.

Wedeen, Lisa. 2003. Seeing like a Citizen, Acting like a State: Exemplary Events in Unified Yemen. Comparative Studies in Society and History 45, 4: 680-713.

Weinstein, Jeremy. 2007. Inside Rebellion: The Politics of Insurgent Violence. Cambridge: Cambridge University Press.

Whitaker, Mark. 2007. Learning Politics from Sivaram: The Life and Death of a Revolutionary Journalist in Sri Lanka. London: Pluto Press.

Wickramasinghe, Nira. 2006. Sri Lanka in the Modern Age: A History of Contested Identities. London: Hurst.

Winslow, Deborah and Michael Woost, eds. 2004. Economy, Culture, and Civil War in Sri Lanka. Bloomington: Indiana University Press.

Wood, Elisabeth. 2008. The Social Processes of Civil War: The Wartime Transformation of Social Networks. Annual Review of Political Science 11: 539-61.

Wood, Elisabeth. 2009. Armed Groups and Sexual Violence: When Is Wartime Rape Rare? Politics \& Society 37, 1: 131-61. 
Abstract: This article uses the case of the Liberation Tigers of Tamil Eelam (LTTE) to make a conceptual argument about sovereignty. Despite its aura of natural order, sovereignty is ultimately self-referential and thus somewhat arbitrary and potentially unstable. At the heart of this unsteadiness, we posit, lies the paradox between the systematic tenets of rational governance and the capricious potential of sublime violence. Both are highly relevant to the LTTE case: the movement created de facto state institutions to mimic governance, but simultaneously deployed an elaborate transcendental register of sacrifice, meaning, and intractable power wielded by a mythical leader. To capture this paradox, we connect the literature on rebel governance with anthropological debates about divine kingship. We conceptualize sovereignty as a citational practice that involves the adaptation, imitation, and mutation of different idioms of authority: political and religious, modern and traditional, rational and mythical. Understanding sovereignty in this way debunks the idea that insurgent movements are merely lagging behind established states. As sites of mimicry, bricolage, and innovation, they transform the way sovereignty is practiced and understood, thus affecting the frame that sovereignty is.

Key words: sovereignty, civil war, rebel governance, divine kingship, mimicry, violence, Sri Lanka 